\title{
Encouraging Literacy in Mathematics Teaching and Learning: Junior High School Teachers' Perspectives
}

\author{
Netti Lastiningsih*, Soedjarwo Soedjarwo, Toho Cholik Mutohir \\ ${ }^{1}$ Postgraduate programme on educational managament, Universitas Negeri Surabaya, Kampus Unesa Ketintang, Surabaya, \\ Indonesia \\ nettismp6sda@gmail.com
}

\author{
Tatag Yuli Eko Siswono \\ Mathematic Department, Universitas Negeri Surabaya, Kampus Unesa Ketintang, Surabaya, Indonesia
}

\begin{abstract}
School literacy program (SLP) tries to nurture the attitude of noble character to children through reading activities, since such activities are believed to become a reflective, analytical, and critical skill leading to the development of other disciplines including mathematics. Consequently program literacy needs to be applied in classroom learning by mathematics teachers. Thus, the aims of this study is to explore teachers' perspectives toward the management of learning and teaching mathematics by involving literacy activities. Fifty-eight mathematics teachers at junior high school were invited to fill out a set of questionnaire consisting of 14 items related to literacy activities in teaching and learning mathematics. The teachers' responses on this set of items were then analyzed by studying the tendency of whether they get used to carry out the examined activities by the items or not based on each item frequency. Generally, results indicate that all the literacy activities within the set of items have already been carried out by teachers, although not all teachers have implement it in their teaching practices. All teachers admitted to have 15-minutes habituation of reading, ask students to pose questions which relates various learning resources being read. This situation picturing potential activities to develop teachers' professionalism in improving literacy.
\end{abstract}

Keywords-literacy; mathematics teaching; mathematics learning; teachers' perspective; school literacy programme.

\section{INTRODUCTION}

When learning mathematics students are often confronted to solve problems. Suppose "A rectangle with an area of 24 units area and a circumference of 20 units of length. Determine the size of the rectangle!" Students often have errors by answering $24 \times 20$ or 640 or 44 . This happens because they do not read the problem information carefully and thoroughly. This situation illustrates the needs for reading skills in solving problems and understanding information well. The evidence of the weakness in solving mathematics and reading problems is reflected in the international assessment report on Indonesian students. Some international surveys of PISA (Program for International Student Assessment), TIMSS (Trends in International Mathematics and Science Study), and PRLS (Progress in International Reading Literacy Study) report on insignificant improvements of Indonesian students in mathematical literacy, science literacy, reading literacy. The score of PISA 2015 in mathematics field is 397, which is below the overall average score of 493. In science literacy, it shows an average score of 403, which is also below the overall average score of 493 [1]. In addition, TIMSS result also shows that Indonesian fourth grade students get a score of 397 for math and science under an average of 500 [2]. The score of the PIRLS of fourth grade students in Indonesia in 2011 was 428 , which is below the standard average of 500 [3]. Reading is believed to be a reflective, analytical, and critical skill, leading to the development of other fields of ability such as math or science. The ability to read is related to the ability of mathematics and science ([4], [5]).

These conditions encourage the ministry of national education and culture develop school literacy program (SLP). SLP is a program to strengthen the movement of character development. One of the activities in the program is a 15 minutes activity of reading a non-learning book before teaching and learning progress begins. This activity is conducted to foster learners' interest in reading and improve reading skills so that their knowledge increases. The reading material contains the values of character, in the form of local, national, and global wisdom that is delivered according to the stage of development of learners. School Literacy in the SLP context is the ability to access, understand, and use something intelligently through various activities, including reading, viewing, listening, writing, and / or speaking [6]. The general purpose of SLP is to develop the character of learners through the culture of the school literacy ecosystem embodied in the SLP so that they become lifelong learners. Meanwhile, the specific objectives of SLP such as to foster a culture of literacy in schools, to increase the capacity of citizens and the school environment for literacy, and make the school as fun and childfriendly learning park so that the students can manage their knowledge well.

The implementation of SLP consists of 3 stages, namely: (1) habituation: the growth of reading interest through such as activities 15 minutes reading, daily reading journal, creating a text-rich environment [7]; (2) development: improving literacy skills through enrichment activities; and (3) learning: improving literacy skills in all subjects: using enrichment books and reading strategies in all subjects. The implementation of the school literacy movement depends on 
the role of the principal in managing the program and mobilizing students, teachers, and all elements of the school. Survey results of principals of junior high schools in Sidoarjo district, East Java, show that the management of SLP is still not optimal, especially in the development and learning stage. All schools have a 15-minute reading program at the beginning, during, and the end of learning [8]. There are still shortcomings and limitations in design and management. For example, there are $79.2 \%$ of schools that have not yet completed the source of learning texts in the school room, corridor, or in the school area. There are $62.5 \%$ of principals and administrative staff who have not been involved in the program.

At the stage of learning, the teacher's role in supporting the SLP is very strategic and crucial for teachers as a model, designer of learning, and support the development and habituation on literacy programs. Such support requires knowledge, skill, commitment and positive perspective teachers. In fact, information of the teacher's perspective of the literacy program in the classroom is limited mainly in teaching and learning activities. Therefore, it is disclosed that deficiencies and problems can be overcome or look for the best solution. Finally, the aims of this study is to explore teachers' perspectives toward the management of learning and teaching mathematics by involving literacy activities.

\section{METHODS}

This descriptive-explorative research was carried out by collecting data about the teachers' responses. Data collection was done by questionnaire [9]. The questionnaire was given to 58 junior high school teachers of which involved in the upgrading of national curriculum 2013. The teachers involved were math teachers from 38 districts / cities as well as district / city instructors. Participant consists of 32 male teachers and 26 female teachers. The questionnaire consists of 14 items with a choice of "Yes" and "No" and related to literacy activities in teaching and learning mathematics. The items are categorized in 3 groups, namely items in beginning of learning activities ( 5 items), during learning ( 7 items), and the end of learning (2 item). The teachers' responses on this set of items were then analyzed quantitatively by studying the tendency of whether they get used to carry out the examined activities by the items or not based on each item frequency.

\section{RESULTS AND DISCUSSION}

Generally, results indicate that all the literacy activities within the set of items have already been carried out by teachers, although not all teachers have implement it in their teaching practices.

Teachers' responses toward implementation of SLP in teaching and learning are presented in table 1 below.

\section{TABLE I: TEACHERS' RESPONSES}

\begin{tabular}{|c|c|c|c|}
\hline No & Indicators & Yes & No \\
\hline 1 & $\begin{array}{l}\text { I am very enthusiastic about the } 15 \text { minute } \\
\text { reading activities conducted at the school. }\end{array}$ & $100.0 \%$ & $0.0 \%$ \\
\hline 2 & $\begin{array}{l}\text { In my class, I becomes a model in the } 15 \\
\text { minute activity of reading by reading } \\
\text { during the activity. }\end{array}$ & $81.0 \%$ & $19.0 \%$ \\
\hline 3 & $\begin{array}{l}\text { I was applying literation in teaching and } \\
\text { learning activities of mathematics. }\end{array}$ & $43.1 \%$ & $56.9 \%$ \\
\hline 4 & $\begin{array}{l}\text { At beggining of the lesson, I ask students } \\
\text { to identify the aim of the reading }\end{array}$ & $10.3 \%$ & $89.7 \%$ \\
\hline 5 & $\begin{array}{l}\text { At beggining of the lesson, I ask students } \\
\text { to make predictions of the readings given. }\end{array}$ & $53.4 \%$ & $46.6 \%$ \\
\hline 6 & $\begin{array}{l}\text { During the lesson, I ask students to } \\
\text { identify relevant information. }\end{array}$ & $41.4 \%$ & $58.6 \%$ \\
\hline 7 & $\begin{array}{c}\text { During the lesson, I ask students to } \\
\text { identify some new terms, keywords, and/or } \\
\text { difficult words/terms at topics which was } \\
\text { learning. }\end{array}$ & $20.7 \%$ & $79.3 \%$ \\
\hline 8 & $\begin{array}{l}\text { During the lesson, I ask students to } \\
\text { identify a part of topics which have } \\
\text { difficulty to understand. }\end{array}$ & $27.6 \%$ & $72.4 \%$ \\
\hline 9 & $\begin{array}{l}\text { During the lesson, I ask students to make } \\
\text { conclusion based on informations which is } \\
\text { written at the text/reading book. }\end{array}$ & $53.4 \%$ & $46.6 \%$ \\
\hline 10 & $\begin{array}{l}\text { When learning activities, I ask students to } \\
\text { make questions about the content of } \\
\text { text/reading books related the mathematics } \\
\text { topics. }\end{array}$ & $82.8 \%$ & $17.2 \%$ \\
\hline 11 & $\begin{array}{l}\text { When learning activities, I ask students to } \\
\text { make connections among texts from } \\
\text { different learning resourses and relevant to } \\
\text { topics. }\end{array}$ & $100.0 \%$ & $0.0 \%$ \\
\hline 12 & $\begin{array}{l}\text { In learning, I ask students to make a } \\
\text { summary (it can be a summarize content, } \\
\text { identify substantial material, retell } \\
\text { theories, make questions about content, } \\
\text { themes, etc.) }\end{array}$ & $86.2 \%$ & $13.8 \%$ \\
\hline 13 & $\begin{array}{l}\text { In ending of learning, after students read } \\
\text { related theories, I ask students to confirm, } \\
\text { revise, or reject the prediction } \\
\text { (hypothesis). }\end{array}$ & $17.2 \%$ & $82.8 \%$ \\
\hline 14 & $\begin{array}{l}\text { To help students understand the reading of } \\
\text { theories related to the material being } \\
\text { studied, I asked students to use tools, such } \\
\text { as check lists, tables, graphs, etc. }\end{array}$ & $17.2 \%$ & $82.8 \%$ \\
\hline
\end{tabular}

Table 1 shows that teachers generally committed and enthusiastic to implement and support the school literacy movement $(100 \%)$. Teachers realized that in their classroom, they become a role model in literacy program $(81 \%)$. Teachers stated that they have not implement literacy in their teaching and learning activities yet $(56.9 \%)$. This condition, in line with next responses. Most teachers at the beginning of the instruction have not teach students to identify the topic objective $(89.7 \%)$ and make predictions (46.6\%). This condition reinforces data about teachers having weaknesses primarily on problem solving of the content knowledge [10]. The weakness is made possible because teachers are not skilled in assigning tasks to predict the completion or problem purpose. The basic ability to understand the problem has not been maximally trained to the students.

Due to at the beggining stage, most teachers have not prepared to design the lesson plan related to the literacy movement, so during the lesson they have not conducted literacy activities. They did not pratice to identify relevant 
information with students when solving a problem (58.6\%). Students have not identified some new terms, keywords, and/or difficult words/terms of the discussed topics (79.3\%). Students are not given the opportunity to identify topics that are still difficult (72.4\%). Teachers may not reflect on learning. Teacher ask students to make conclusion based on informations which is written at the text/ reading book (53.4\%). Most teachers ask students to pose questions about the content of text/reading books related the mathematics topics $(82,8 \%)$, to make connections between topics $(100 \%)$, and make a summary $(86.2 \%)$.

At the end of learning, most teachers have not asked students to confirm, revise, or reject the prediction/hypothesis $(82.8 \%)$ and have not adviced students to use tools, such as check lists, tables, graphs, etc $(82.8 \%)$. Teacher's teaching process still looks traditional, and do not emphasize the problem solving that becomes the focus of learning. Literacy activities have not been a priority and are not associated with problem-solving activities. Teacher's knowledge seems to be an obstacle in these point of view. As a government policy, literacy has been the concern of teachers but still have not reached the stage of development and learning yet [6].

\section{CONCLUSION}

The results show that teachers' perspective in teaching and learning management related to literacy is still not optimal. All teachers admitted to have 15-minutes habituation of reading, and ask students to pose questions which relates various learning resources being read (100\%). While most teachers ( $20.7 \%$ to $82.8 \%)$ admitted to carry out some items during learning activities such as asking students to make a temporary summary of learning activities and final summary of topic in mathematics that have been studied, only few teachers $(17.2 \%)$ who have implemented the end of learning activities such as encouraging students to revise, clarify, or refute any predicition based on the theory they have learned.

Results of this study support the idea of the need for mathematics teachers to involve literacy activities as much as possible in their teaching practice. This situation may occur not only in the mathematics teacher where the teaching management does not implement the literacy program. Teachers may not have the knowledge, skills, and strategies to include literacy in their teaching and learning. The follow up of this research is to develop a professional development involving teachers and principals effectively and credible so that it can be applied at all levels of the school.

\section{ACKNOWLEDGMENTS}

We would like to thank the rector of Universitas Negeri Surabaya, the postgraduated director of Universitas Negeri Surabaya, and all teachers as the partipants involved in this programme.

\section{REFERENCES}

[1] OECD, "Reading Literacy Framework", (https://www.oecd.org/pisa/pisaproducts/Draft\%20PISA\%202015\%20R eading\%20Framework\%20.pdf), 2015.

[2] M. O. Martin, I. V. S. Mullis, P. Foy, and M. Hooper, "TIMSS 2015 International Results in (http://timssandpirls.bc.edu/timss2015/international-results/), 2016.

[3] TIMSS and PIRLS, "Overview TIMSS and PIRLS", (https://timssandpirls.bc.edu/data-release-2011/pdf/Overview-TIMSSand-PIRLS-2011-Achievement.pdf), 2011.

[4] O. A. Imam, "Effects of Reading Skills on Students' Performance in Science and Mathematics in Public and Private Secondary Schools", Journal of Education and Learning, vol. 10(2), pp. 177-186, 2016.

[5] B. Armbruster, "Science and reading", The Reading Teacher, vol.46(4), pp. 346-347, 1992.

[6] P. Retnaningdyah, et.al., Panduan Gerakan Literasi Sekolah di Sekolah Menengah Pertama. Jakarta: Direktorat Jenderal Pendidikan Dasar dan Menengah Kementerian Pendidikan dan Kebudayaan, 2016.

[7] Permendikbud, Peraturan No 23 tahun 2015 tentang penumbuhan budi pekerti. Jakarta: Ministry of Education, 2015.

[8] N. Lastiningsih, T.C Muthohir, Y. Riyanto, and T.Y.E. Siswono, "Management of the school literacy movement (SLM) programme in Indonesian junior secondary schools", World Transactions on Engineering and Technology Education (WIETE) vol.15(4)4, 2017

[9] T.Y.E. Siswono, Penelitian Pendidikan Matematika. Surabaya: Unipress Unesa, 2008.

[10] T. Y. E. Siswono, A. W. Kohar, and S. Hartono, "Secondary Teachers' Mathematics-Related Beliefs and Knowledge about Mathematical Problem-Solving”, Journal of Physics: Conference Series, vol. 812(1). 